\title{
MAGNESIUM ABSORPTION FROM DIFFERENT COMPARTMENTS OF THE SWINE LARGE INTESTINE
}

\author{
S. MILINKOVIĆ-TUR, Z. STOJEVIĆ, B. GRADINSKI-VRBANAC, M. ŠIMPRAGA \\ Department of Physiology and Radiobiology, Faculty of Veterinary Medicine, University of Zagreb, \\ Zagreb, Republic of Croatia \\ Received September 27, 1999 \\ Accepted February 10, 2000
}

\section{Abstract}

Milinković-Tur S., Z. Stojević, B. Gradinski-Vrbanac, M. Šimpraga: Magnesium Absorption From Different Compartments of the Swine Large Intestine. Acta Vet. Brno 2000, 69: 3-9.

We studied magnesium absorption in the distal part of the swine intestine as a function of different magnesium concentrations in the contents that may affect its absorption rate. The study was carried out in vitro by using sacs made of surviving mucous membrane of the caecum and proximal colon. The sacs were filled with magnesium chloride solutions containing magnesium at $0.5,1.0,2.5,5,10$ or $20 \mathrm{mmol} / \mathrm{L}$. The samples were collected on the submucosal side of the mucous membrane at the beginning of the experiment and 30, 60, 120 and 180 minutes later. Magnesium concentration in the samples was determined spectrophotometrically using the Titan yellow method. Increase of its concentration on the submucosal side was noticed already after 30 minutes from both compartments at all magnesium concentrations in the contents $(\mathrm{P}<0.001)$. According to the presented results, at the lowest magnesium concentration in the contents, its absorption against the concentration gradient is possible from both compartments. The increase of magnesium concentration in the contents to 10 or $20 \mathrm{mmol} / \mathrm{L}$ was accompanied by a significant increase of its absorption from both compartments $(\mathrm{P}<0.001)$. The lowest absorption rate of magnesium was achieved at $5 \mathrm{mmol} / \mathrm{L}$ of magnesium in the contents. The epithelium of the caecum was less resistant to low and proximal colon to high magnesium concentration in the content. Our results indicate that the distal part of the swine digestive tract, i.e. the caecum and proximal colon, represent important sites of the magnesium absorption where magnesium was mostly absorbed by passive transport.

Magnesium absorption, swine caecum, proximal colon

Numerous studies were performed to determine the sites of the highest magnesium absorption in the digestive tract of various animal species and the complexity of the digestive epithelium, as the absorption membrane, represented an important model for the investigation of the manner of the magnesium transport. Research studies carried out on rats reported on magnesium absorption in the small intestine (Ald or and Moore 1970; B ehar 1974) and in the large intestine (Chutkow 1964; Meneely et. al. 1982; Younes et. al. 1996).

Although there are many contradictory data in the literature about the main site of magnesium absorption from the digestive tract, the opinion prevails that large intestine in monogastric animals and forestomachs in the ruminants are the main sites of its absorption (Hurley et. al. 1990; Meyer and Zentek 1990; Rahnema and Fontenot 1990; Rahnema et. al. 1994). Only few authors indicate the distal part of the digestive tract, i.e. the ileum and colon, as the main site of the magnesium absorption in the swine digestive tracts (Partridge 1978).

Magnesium absorption has an essential role in the supply of organisms with this important mineral and in the maintenance of its overall balance in the body ( $\mathrm{Günther} \mathrm{1990).} \mathrm{One} \mathrm{of}$ the essential factors influencing magnesium absorption rate is its concentration in the

Address for correspondence:

Suzana Milinković-Tur, D.Sc.,
Department of Physiology and Radioiology

Faculty of Veterinary Medicine Univerity of Zagreb

Heinzelova 55, 10000 Zagreb, Croatis
Phone: +38512390171

Fax: +3851244 13

http://www.vfu.cz/acta-vet/actavet.htm 
contents of the digestive tract. It is generally considered that, at low concentrations, magnesium is absorbed linearly, while the increase of its concentration in the digestive tract content does not coincide with a linear increase of its transport in the direction of the absorption (Behar 1975; Karbach and Rummel 1990). The saturation of the magnesium transport at its elevated levels is attributed to a reduced permeability of the absorption membrane (Tidball 1964), reduced magnesium transport due to the solvent drag (Behar 1975) and transport by facilitated diffusion, the capacity of which becomes saturated with time (Stojević and Timet 1983). The saturation of magnesium transport in the absorption direction in the presence of metabolic inhibitors also indicates the possibility of the existence of its active transport across the mucous membrane of the rumen (Martens 1983; Martens et. al. 1988), and across the small intestine of the guinea pig (Hayashi and Hoshi 1992).

The purpose of our study was to investigate magnesium absorption in two different compartments of the distal part of the swine digestive tract as a function of different magnesium concentrations that may affect its absorption rate.

\section{Materials ad Methods}

The experiments were carried out in vitro using sacs made of the surviving mucous membrane of the swine caecum and proximal colon. The pigs originated from a farm where common pig rearing technology was used. The animals were fed a commercially available fattening feed mixture. At the time of slaughter, the average liveweight of the pigs ranged between 90 and $110 \mathrm{~kg}$. The caecum and the colon were removed immediately upon exenteration and transferred to the laboratory for further processing. After the opening of the caecum and proximal colon, the digesta were first removed mechanically and then their remnants were carefully removed from the surface of the mucous membrane by repeated rinsing with Tyrode solution. Thereafter, the mucous membrane was carefully peeled off the muscular layer and stretched on special glass funnels (diameter $4 \mathrm{~cm}$ ). The epithelial side of the mucous membrane was always facing inwards.

Two identical series of experiments were performed; one with the sacs made of the mucous membrane of swine caecum (12 animals per each concentration) and the other with the sacs made of the mucous membrane of the proximal colon (13 animals per each concentration).

The sacs were filled with $25 \mathrm{ml}$ of the test solution of pure magnesium chloride with magnesium content of 0.5 , $1.0,2.5,5,10$ or $20 \mathrm{mmol} / \mathrm{L}$. Prepared in this way, the sacs were immersed into beakers containing 50 ml of Tyrode's solution. Throughout the experiments the sacs were kept in a thermostat at a temperature of $38^{\circ} \mathrm{C}$, with permanent aeration from outside the sac provided by special Vibro noiseless aquarium pumps.

The samples for the determination of magnesium concentrations were taken from the Tyrode solution that was always on the submucosal side of the mucous membrane, immediately before the beginning of the experiment and 30, 60, 120 and 180 minutes later. Magnesium concentration in the samples was determined spectrophotometrically using the Titan yellow Basinski's method (1965). From the magnesium concentrations determined in the samples taken after each interval, the magnesium concentration that already had existed in the Tyrode solution immediately before the beginning of the experiments was subtracted. The increase of the magnesium concentrations in the samples determined in this way, represented the "net transport" of the magnesium across the mucous membrane in the absorption direction.

The obtained results were statistically evaluated and presented as mean \pm S.E.M. values. The significance of the differences was checked using Student's $t$-test and Fisher's test (Renner 1970).

\section{Results}

Transport of magnesium in the absorption direction when the mucous membrane of the swine caecum was used as the absorption membrane.

The results of this group of experiments are shown in the Table 1.

As soon as after 30 minutes, a significant increase of the magnesium concentration was determined on the submucosal side $(\mathrm{P}<0.001)$ at all concentrations in the solution used on the epithelial side of the mucous membrane.

With the magnesium concentration of $0.5 \mathrm{mmol} / \mathrm{L}$ on the epithelial side of the caecal mucous membrane, concentration on the submucosal side continued to increase significantly in the next interval, i.e. after 60 minutes when it was by approximately $40 \%$ $(\mathrm{P}<0.05)$ higher. The obtained values remained at a similar level until the end of the 
Table 1

Increase of the magnesium concentration in $\mathrm{mmol} / \mathrm{L}$ on the submucosal side of the mucous membrane of the swine caecum when, on the epithelial side, there was a magnesium chloride solution containing magnesium at $0.5,1.0$, $2.5,5,10$ and $20 \mathrm{mmol} / \mathrm{L}$

\begin{tabular}{|c|c|c|c|c|}
\hline \multirow{2}{*}{$\begin{array}{c}\mathrm{Mg}^{2+} \text { concentration } \\
\text { on the epithelial } \\
\text { side }\end{array}$} & \multicolumn{4}{|c|}{$\mathrm{Mg}^{2+}$ concentration on the submucosal side after experimental periods in minutes } \\
\cline { 2 - 5 } & 30 & 60 & 120 & 180 \\
\hline $0.5 \mathrm{mmol} / \mathrm{L}$ & $0.25 \pm 0.03$ & $0.35 \pm 0.02^{\mathrm{a}}$ & $0.32 \pm 0.03$ & $0.32 \pm 0.03$ \\
$1.0 \mathrm{mmol} / \mathrm{L}$ & $0.35 \pm 0.03$ & $0.41 \pm 0.03$ & $0.45 \pm 0.04$ & $0.49 \pm 0.05^{\mathrm{b}}$ \\
$2.5 \mathrm{mmol} / \mathrm{L}$ & $0.35 \pm 0.03$ & $0.44 \pm 0.03$ & $0.49 \pm 0.05^{\mathrm{a}}$ & $0.47 \pm 0.06$ \\
$5 \mathrm{mmol} / \mathrm{L}$ & $0.22 \pm 0.02$ & $0.26 \pm 0.02$ & $0.33 \pm 0.03^{\mathrm{c}}$ & $0.32 \pm 0.02^{\mathrm{c}}$ \\
$10 \mathrm{mmol} / \mathrm{L}$ & $0.23 \pm 0.02$ & $0.36 \pm 0.03^{\mathrm{c}}$ & $0.48 \pm 0.04^{\mathrm{d}}$ & $0.82 \pm 0.10^{\mathrm{d}}$ \\
$20 \mathrm{mmol} / \mathrm{L}$ & $0.30 \pm 0.03$ & $0.58 \pm 0.04^{\mathrm{d}}$ & $1.29 \pm 0.08^{\mathrm{d}}$ & $1.41 \pm 0.22^{\mathrm{d}}$ \\
\hline
\end{tabular}

Average values of 12 determinations \pm S. E. M.; asterisks indicate significant differences as compared with the first interval: ${ }^{\mathrm{a}} \mathrm{P}<0.05,{ }^{\mathrm{b}} \mathrm{P}<0.025,{ }^{\mathrm{c}} \mathrm{P}<0.005,{ }^{\mathrm{d}} \mathrm{P}<0.001$.

experiments. When the solution with $1.0 \mathrm{mmol} / \mathrm{L}$ was used for filling the sacs, the magnesium concentration on the submucosal side increased almost linearly throughout the experiments. At the end of the experiments, the increase of some $40 \%$ compared to the first experimental period was statistically significant $(\mathrm{P}<0.025)$. Similarly, with a solution containing $2.5 \mathrm{mmol} / \mathrm{L}$ of magnesium, its concentration on the submucosal side of the mucous membrane gradually increased towards the end of the 120-minute interval when this increase amounted to approximately $40 \%$, which was considerably higher than in the first interval $(\mathrm{P}<0.05)$. Similar concentrations were maintained until the end of the experiments.

When the solution with high magnesium concentration $(5,10$ or $20 \mathrm{mmol} / \mathrm{L})$ was introduced from the epithelial side of the caecal membrane, already after 30 minutes, its passage in the direction of absorption followed the rise of magnesium concentration in the solution. Such trend could be observed in all other intervals, too, and became increasingly significant with the duration of the experiments. With the solution containing magnesium at $5 \mathrm{mmol} / \mathrm{L}$, its concentrations obtained from the submucosal side, rose gradually towards the end of the experiments. These increases of approximately 50\% and 45\% after 120 and 180 minutes, respectively, were statistically significant compared to the first interval $(\mathrm{P}<0.005)$.

When the magnesium concentration in the solution was increased to $10 \mathrm{mmol} / \mathrm{L}$, its transport in the direction of absorption increased until the end of the experiments. At all intervals, the obtained values were significantly higher compared to those of the first interval. At the end of the experiments, i.e. after 180 minutes, the values almost doubled and were by approximately $71 \%$ higher than in the preceding interval $(\mathrm{P}<0.01)$. At the same time, the values exceeded those obtained from the solution with magnesium content between 0.5 and $5 \mathrm{mmol} / \mathrm{L}$.

With a solution containing magnesium at $20 \mathrm{mmol} / \mathrm{L}$ on the epithelial side of the mucous membrane, the absorption rate of magnesium significantly increase during the experiment. After 60 minutes, the magnesium concentrations on the submucosal side of the mucous membrane almost doubled and were increased by about $95 \%(\mathrm{P}<0.001)$. This rising trend continued in the subsequent interval, after 120 minutes, when the values doubled again and were by some $120 \%$ higher $(\mathrm{P}<0.001)$. At the end of the experiments, the transport of magnesium in the absorption direction slightly slowed down. The transport of magnesium after 30 minutes was higher only when compared to its transport from the solution with the lowest magnesium concentration, i.e. $0.5 \mathrm{mmol} / \mathrm{L}$. From the next interval until the end of the experiment the obtained values exceeded the values determined at all magnesium concentrations in the solution. 
Transport of magnesium in the absorption direction when the mucous membrane of the swine proximal colon was used as the absorption membrane.

The results of this experimental series are shown in the Table 2.

Table 2

Increase of the magnesium concentration in $\mathrm{mmol} / \mathrm{L}$ on the submucosal side of the mucous membrane of the swine proximal colon when, on the epithelial side, there was a magnesium chloride solution containing magnesium at $0.5,1.0,2.5,5,10$ and $20 \mathrm{mmol} / \mathrm{L}$

\begin{tabular}{|c|c|c|c|c|}
\hline \multirow{2}{*}{$\begin{array}{c}\mathrm{Mg}^{2+} \text { concentration } \\
\text { on the epithelial } \\
\text { side }\end{array}$} & \multicolumn{3}{|c|}{$\mathrm{Mg}^{2+}$ concentration on the submucosal side after experimental periods in minutes } \\
\cline { 2 - 5 } & 30 & 60 & 120 & 180 \\
\hline $0.5 \mathrm{mmol} / \mathrm{L}$ & $0.15 \pm 0.02$ & $0.28 \pm 0.05^{\mathrm{b}}$ & $0.30 \pm 0.03^{\mathrm{d}}$ & $0.27 \pm 0.03^{\mathrm{b}}$ \\
$1.0 \mathrm{mmol} / \mathrm{L}$ & $0.21 \pm 0.02$ & $0.41 \pm 0.06^{\mathrm{c}}$ & $0.38 \pm 0.04^{\mathrm{d}}$ & $0.38 \pm 0.03^{\mathrm{e}}$ \\
$2.5 \mathrm{mmol} / \mathrm{L}$ & $0.19 \pm 0.03$ & $0.32 \pm 0.04^{\mathrm{b}}$ & $0.45 \pm 0.05^{\mathrm{d}}$ & $0.39 \pm 0.03^{\mathrm{e}}$ \\
$5 \mathrm{mmol} / \mathrm{L}$ & $0.10 \pm 0.01$ & $0.21 \pm 0.03^{\mathrm{a}}$ & $0.37 \pm 0.04^{\mathrm{d}}$ & $0.34 \pm 0.02^{\mathrm{d}}$ \\
$10 \mathrm{mmol} / \mathrm{L}$ & $0.30 \pm 0.03$ & $0.54 \pm 0.06^{\mathrm{d}}$ & $0.68 \pm 0.04^{\mathrm{e}}$ & $1.11 \pm 0.13^{\mathrm{e}}$ \\
$20 \mathrm{mmol} / \mathrm{L}$ & $0.45 \pm 0.08$ & $0.72 \pm 0.08^{\mathrm{a}}$ & $2.07 \pm 0.28^{\mathrm{e}}$ & $2.07 \pm 0.29^{\mathrm{e}}$ \\
\hline
\end{tabular}

Average values of 13 determinations \pm S. E. M.; asterisks indicate significant differences as compared with the first interval: ap $<0.05,{ }^{\text {b }}<0.02,{ }^{\mathrm{c}} \mathrm{P}<0.01,{ }^{\mathrm{d}} \mathrm{P}<0.005$, ${ }^{\mathrm{e}} \mathrm{P}<0.001$.

Like in the first series of experiments, after 30 minutes from the beginning of an experiment, an increase of magnesium concentration on the submucosal side was observed at all concentrations in the solution, at the level of significance $\mathrm{P}<0.001$.

When the mucous membrane of the proximal colon was used as the absorption membrane, and the sacs were filled with a solution containing magnesium at low concentrations, i.e. 0.5, 1.0 or $2.5 \mathrm{mmol} / \mathrm{L}$, its transport in the absorption direction did not coincide with the increase of its concentration in the content. So the transport of magnesium in the absorption direction after 30 minutes was the most intensive at its concentration of $1.0 \mathrm{mmol} / \mathrm{L}$, then at the concentration of $2.5 \mathrm{mmol} / \mathrm{L}$ and the least intensive transport was observed from the solution containing magnesium at $0.5 \mathrm{mmol} / \mathrm{L}$. Anyway, at the magnesium concentrations of $0.5,1.0$ or $2.5 \mathrm{mmol} / \mathrm{L}$ in the solution, a significant increase of the magnesium concentration on the submucosal side of the mucous membrane was noted during the experiments. With the solution containing magnesium at $2.5 \mathrm{mmol} / \mathrm{L}$, only after 120 minutes, the magnesium concentrations determined on the submucosal side of the mucous membrane exceeded the values determined with the solutions containing magnesium at 0.5 and $1.0 \mathrm{mmol} / \mathrm{L}$.

When the solution contained magnesium at the concentrations of 5, 10 and $20 \mathrm{mmol} / \mathrm{L}$, the resistance of the mucous membrane of the proximal colon significantly weakened with the increase of its concentration in the solution throughout the experiment. Although with the magnesium concentration of $5 \mathrm{mmol} / \mathrm{L}$ in the contents the transport of magnesium in the $60^{\text {th }}$ minute of the experiment was increased by $113 \%(\mathrm{P}<0.05)$, and after 120 minutes by further $80 \%(\mathrm{P}<0.005)$ and remained at these values until the end of the experiments, this transport was higher only when compared to that from the solution with the lowest magnesium concentration in the contents, i.e. $0.5 \mathrm{mmol} / \mathrm{L}$.

The increase of the magnesium concentration in the contents to 10 and $20 \mathrm{mmol} / \mathrm{L}$ significantly improved the transport of magnesium in the direction of absorption throughout the experiments. At the magnesium concentration of $10 \mathrm{mmol} / \mathrm{L}$ in the content, at the end of the experiments, i.e. after 180 minutes, the values were by $62 \%$ higher than those determined in the preceding interval $(\mathrm{P}<0.01)$. In all intervals, the transport of magnesium exceeded 
the values obtained from the test solutions at all above mentioned magnesium concentrations. At its concentration of $20 \mathrm{mmol} / \mathrm{L}$, after 60 minutes, the values increased by about 59\% ( $\mathrm{P}<0.05$ ), after 120 minutes the values almost doubled and were by approximately $188 \%$ higher than in the preceding interval $(\mathrm{P}<0.001)$. They remained at the same level at the end of the experiments. At magnesium concentration of $20 \mathrm{mmol} / \mathrm{L}$, its transport in the absorption direction was more intensive than that from the solution containing $10 \mathrm{mmol} / \mathrm{L}$ of magnesium in all experimental periods.

\section{Discussion}

The results of the experiments show that the mucous membrane of the swine caecum and proximal colon is permeable for the transport of magnesium in the absorption direction, i.e. from the epithelial towards the submucosal side of the mucous membrane. The absorption rate of magnesium depended on the kind of the mucous membrane used and on the concentration of magnesium contained therein.

Considering that in both examined compartments of the swine large intestine, magnesium absorption was determined at its concentration of $0.5 \mathrm{mmol} / \mathrm{L}$ in the contents, the results undoubtedly show that in the distal part of the swine digestive tract, magnesium may be transported against a concentration gradient. The obtained results are in agreement with the opinion expressed by Behar (1974) and Karbach and Rummel (1990). In this respect, Behar (1974) and Karbach (1989) indicate the "solvent drag" as the main mode of the magnesium transport against a concentration gradient. In the present study, the magnesium transport against a concentration gradient may also be correlated to the water transport, meaning that under such condition magnesium was, at least partially, absorbed by the solvent drug.

When the sacs were filled with a solution of magnesium at $1.0 \mathrm{mmol} / \mathrm{L}$, which corresponds to the level of intracellular ionized magnesium, "net transport" of magnesium to the submucosal side of the mucous membrane probably occurred by a simple diffusion, mainly due to the electrochemical potential and less to the concentration gradient. Under such conditions, Beyenbach (1990) also attributes the magnesium influx into the cells to the diffusion of magnesium through the membrane channels, which is, to a greater extent due to the electrochemical potential than to the difference in the magnesium concentration. When magnesium concentration in the solution was increased to $2.5 \mathrm{mmol} / \mathrm{L}$, its absorption through both examined epithelia also occurred by simple diffusion according to concentration gradient and electrochemical potential.

An increased resistance of both examined epithelia to magnesium transport in the direction of absorption from solution containing $5 \mathrm{mmol} / \mathrm{L}$ of magnesium may be a consequence of an "anomaly" in the magnesium transport by solvent drug mentioned by Karbach and Rummel (1990). In their studies, at the same magnesium concentration in the content of rat ileum magnesium secretion surpassed its absorption. The authors attributed this increased magnesium secretion to a possible "anomaly" of the magnesium transport by the solvent drug. The mucous membrane of the distal part of the swine digestive tract (Traynor et al. 1991) as well as of the rat colon and ileum (Karbach 1989; Karbach and Rummel 1990) is permeable both in the absorption and secretion directions. Consequently, the mentioned results of this research could be attributed, at least in part, to the "anomaly" of the magnesium transport by the solvent drag, but also to the changes of the electrochemical properties of the membranes themselves.

The most intensive magnesium absorption from swine caecum and proximal colon was achieved from the solution containing 10 and $20 \mathrm{mmol} / \mathrm{L}$ of magnesium in the content. In both compartments of the swine large intestine examined in this study the saturation of magnesium absorption process could not be obtained. In our earlier studies, the increase of 
the magnesium concentration in the contents of swine caecum from 10 to $50 \mathrm{mg} / 100 \mathrm{~mL}$ resulted in a similar rise in the solution from the submucosal side of the epithelium (Stoje vić et al. 1993). It allows one to suppose that the main magnesium absorption in both examined epithelia is due to the process of passive transport mechanisms, mainly by simple diffusion due to the concentration gradient. Beyenbach (1990) also indicates that active magnesium transport is more a hypothesis than a proven fact.

Better absorption of magnesium from the solution containing low magnesium concentration obtained in the caecum, and its better absorption from the high magnesium concentration in proximal colon pointed to different properties of these two epithelia, resulting in their different absorptive characteristics.

The mucous membrane of the proximal colon is considered to be more permeable to liquids and ions than the caecal mucous membrane, whether due to the difference in the size and number of pores, or due to a more intensive paracellular transport (Sellin and DeSoignie 1984) which probably resulted in a more intensive magnesium absorption in this particular compartment of the swine digestive tract at higher magnesium concentrations in the content.

It can be concluded that the distal part of the swine digestive tract, i.e. the caecum and proximal colon, represent important sites of the magnesium absorption where, according to our results, magnesium was mostly absorbed by passive transport.

\section{Resorpce hořčíku z různých oddílů tlustého střeva prasete}

V pokusu byla sledována resorpce hořčíku z distální části střeva prasete jako funkce různých koncentrací $\mathrm{Mg}^{2+} \mathrm{v}$ obsahu střevním. Ve studii in vitro byly použité váčky zhotovené z přežívající sliznice caeca a proximálního colonu. Váčky byly naplněny roztoky $\mathrm{MgCl}_{2}$ s obsahem $\mathrm{Mg} 0,5 ; 1,0 ; 2,5 ; 5 ; 10$ a $20 \mathrm{mmol} / \mathrm{l}$. Vzorky byly odebírány na submukózní straně váčků na počátku experimentu a poté za 30, 60, 120 a 180 minut. Koncentrace hořčíku ve vzorcích byla stanovena spektrofotometricky. Signifikantní vzestup koncentrace hořčíku na submukózní straně byl zaznamenán již po 30 minutách př́i všech sledovaných koncentracích a v obou oddílech střeva $(\mathrm{p}<0.001)$. Z výsledkủ vyplývá, že při nejnižší koncentraci v obsahu váčků byla resorpce hořčíku proti koncentračnímu spádu možná z obou oddílů střeva. Zvýšená koncentrace hořčíku v obsahu váčku na 10 a 20 mmol/l byla doprovázena signifikatním vzestupem resorpce z obou oddílů $(\mathrm{p}<0.001)$.Nejnižší rychlost resorpce hořčíku bylazaznamenána při jeho koncentraci $5 \mathrm{mmol} / \mathrm{l} \mathrm{v}$ obsahu váčku. Epitel caeca je méně resistentní a epitel proximálního colonu je váce rezistentní vůči vysoké koncentraci hořčíku v obsahu váčku. Distální část trávicí trubice prasete, tj. caecum a proximální colon představují významná místa resorpce hořčíku, který byl více resorbován pasivně.

Acknowledgements

This work was supported by the Ministry of Science and Technology of Croatia (Grant No. 3-03-291).

\section{References}

ALDOR, T. A. M., MOORE, D. W. 1970: Magnesium absorption by everted sacs of rat intestine and colon. Gastroenterology 59: 745-753

BASINSKI, D. H. 1965: In: MEITES, S.: Standard Methods of Clinical Chemistry, vol. 5, Academic Press Inc. New York, pp. 137.

BEHAR, J. 1974: Magnesium absorption by the rat ileum and colon. Am. J. Physiol. 227 (2): 334-340

BEHAR, J. 1975: Effect of calcium on magnesium absorption. Am. J. Physiol. 229: 1590-1595

BEYENBACH, K. W. 1990: Transport of magnesium across biological membranes. Magnesium Trace Elem. 9. 233-254

CHUTKOW, J. G. 1964: Sites of magnesium absorption and excretion in the intestinal tract of the rat. J. Lab. Clin. Med. 63: 71-79 
GÜNTHER, T. 1990: Magnesium deficiency generally enhances cytotoxicity. Mag. Bull. 12 (2): 61-64

HAYASHI, H., HOSHI, T. 1992: Properties of active magnesium flux across the small intestine of guinea pig. Jpn. J. Physiol. 42 (4): 561-575

HURLEY, L. A., GREENE, L. W., BYERS, F. M., CARSTENS, G. E. 1990: Site and extent of apparent magnesium absorption by lambs fed different sources of magnesium. J. Anim. Sci. 68: 2181-2187

KARBACH, U. 1989: Cellular-mediated and diffusive magnesium transport across the descending colon of the rat Gastroenterology 96: 1282-1289

KARBACH, U., RUMMEL, W. 1990: Cellular and paracellular magnesium transport across the terminal ileum of the rat and its interaction with the calcium transport. Gastroenterology 98: 985-992

MARTENS, H. 1983: Saturation kinetics of magnesium efflux across rumen wall in heifers. Br. J. Nutr. 49: 153158

MARTENS, H., HEGGEMANN, G., REGIER, K. 1988: Studies on the effect of K, $\mathrm{NH}_{4}{ }^{+}$, VFA and $\mathrm{CO}_{2}$ on the net absorption of magnesium from the temporarily isolated rumen of heifers. J. Vet. Med. A. 35: 73-80

MENEELY, R., LEEPER, L., GHISHAN, F. K. 1982: Intestinal maturation: in vivo magnesium transport. Pediat. Res. 16: 295-298

MEYER, H., ZENTEK, J. 1990: Magnesium in animal nutrition. In: Sigel H., A. Sigel eds. "Metal Ions in Biological Systems", Marcel Dekker, New York, vol. 26: pp. 57-83.

PARTRIDGE, I. G. 1978: Studies on digestion and absorption in the intestines of growing pigs. 3. Net movements of mineral nutrients in the digestive tract. Br. J. Nutr. 39 (3): 527-537

RAHNEMA, S. H., FONTENOT, J. P. 1990: Effect of intravenous infusion of high levels of potassium and sodium on mineral metabolism in sheep. J. Anim. Sci. 68: 2833

RAHNEMA, S., WU Z., OHAJURUKA, O. A., WEISS, W. P., PALMQUIST, D. L. 1994: Site of mineral absorption in lactating cows fed high-fat diets. J. Anim. Sci. 72: 229-235

RENNER, E. 1970: Matematisch-statistische Methoden in der praktischen Anwendung, Paul Parey, Berlin, pp. 37-39

SELLIN, J. H., DESOIGNIE, R. 1984: Rabbit proximal colon: a distinct transport epithelium. Am. J. Physiol. 246 (9): G 603-G610

STOJEVIĆ, Z., TIMET, D. 1983: Magnesium ion absorption in the bovine stomach and its relation to the magnesium level in the content. Vet. arhiv 53: 291-298

STOJEVIĆ, Z., EMANOVIĆ, D., MILINKOVIĆ-TUR, S., OUZEL, S. 1993: Magnesium absorption from the swine caecum. 1. Effect of different magnesium and ammonium concentrations in the content on the intensity of magnesium absorption. Vet. arhiv 63: 265-272

TIDBALL, C. S. 1964: Magnesium and calcium as regulators of intestinal permeability. Am. J. Physiol. 206: 243246

TRAYNOR, T. R., BROWN, D. R., O'GRADY, S. M. 1991: Regulation of ion transport in porcine distal colon: effect of putative neurotransmitters. Gastroenterology 100: 703-710

YOUNES, H., DEMIGNE, C., RÉMÉSY, C. 1996: Acidic fermentation in the caecum increases absorption of calcium and magnesium in the large intestine of the rat. Br. J. Nutr. 75: 301-314 